\section{Evaluating Equipment Acquisition Alternatives}

\author{
Steven C. Blank ${ }^{1}$, \\ Karen Klonsky ${ }^{1}$, and \\ Kim Norris ${ }^{2}$
}

Additional index words. machinery acquisition, break-even analysis, risk, harvest equipment

Summary. We address whether it is better for a producer to own harvesting equipment or hire a custom harvester to perform the job. A comparison of calculated purchase costs with the cost of hiring a custom operator leads to an estimate of the break-even acreage, which is used as a decision criterion. However, two risk factors must be included in the decision process: the date of harvest and the efficiency of the harvest operation. The affect of these factors may significantly alter the "real" costs of owning vs. hiring a custom operator and, therefore, change the decision reached by an individual grower.

W e address whether it is better for a producer to own harvesting equipment or hire a custom operator to perform the job. A financial analysis is presented for three alternate courses of action: 1) purchase new equipment, 2) purchase used equipment, or 3) hire a custom operator.

This type of purchase-vs.-lease decision has been approached in various ways. Some studies have emphasized factors affecting the decision, such as taxes (Franks and Hodges, 1987), asset lives (VanTassel and Nixon, 1989; Weingartner, 1987), and financial risk (Levy and Sarnat, 1979). Alternate methods ofanalysis have also been used, such as internal rate of return (Van Horne, 1989). However,

Extension Economist

${ }^{2}$ Staff Research Associate.

Agricultural Economics Department, University of California, Davis. the preferred method (Boehlje and Eidman, 1984; Hinman and Willet, 1985; Lee et al., 1988) is presentvalue analysis of after-tax cash flows, which is applied here.

The objective of this paper is to illustrate how financial analyses are structured for producers undertaking purchase/lease decisions. As a case study, an analysis of walnut harvesting equipment in California is presented; however, the methods used are relevant to any equipment acquisition decision.

The data used in the analysis were collected during Jan. 1991 in telephone interviews. Respondents were selected using cluster sampling and stratified random sampling techniques to minimize the sample size required (Blank, 1983). First, a sample of the geographic regions of walnut production in California was taken. Second, from those selected clusters located in California's San Joaquin and Sacramento valleys, a stratified random sample of respondents was drawn. The strata included six equipment manufacturers, five custom harvest operators, and five growers.

Using these data, the cost of owning and operating the necessary harvest equipment is estimated over the average period such equipment is held. The estimated cost for both new and used equipment is then compared against the current custom rates to reach a basic conclusion. In the second part of the analysis, risk factors that might affect the basic conclusion for individual growers are evaluated.

\section{Annual ownership and operating costs}

The analysis focuses on the three pieces of equipment required to harvest walnuts: a shaker, a sweeper, and a harvester or pick-up machine with nut trailers. Survey results on the costs and typical performance of this equipment when purchased new or used for a mature orchard appear in Table 1 . Performance will vary depending on the size of the trees and the yield.

The first step in this analysis is to determine the total cash cost of owning and operating harvest equipment. Since there is an active market for used equipment in California, each purchase alternative (new vs. used) is evaluated separately. In each case, it is assumed that the equipment will be financed. 
Table 1. Walnut barvest equipment costs.

\begin{tabular}{|c|c|c|c|c|c|c|}
\hline \multirow[b]{2}{*}{ Equipment $^{x}$} & \multicolumn{2}{|c|}{ Purchase price $(\$)$} & \multirow{2}{*}{$\begin{array}{l}\text { Life } \\
\text { (h) }\end{array}$} & \multirow{2}{*}{$\begin{array}{c}\text { Anmual } \\
\text { repairs (\$) }\end{array}$} & \multirow{2}{*}{$\begin{array}{l}\text { Fuel use } \\
(\mathrm{gal} / \mathrm{h})\end{array}$} & \multirow{2}{*}{$\begin{array}{l}\text { Harvestiug } \\
\text { capacity/h }\end{array}$} \\
\hline & Range & Avg & & & & \\
\hline \multicolumn{7}{|l|}{ New } \\
\hline Shaker ${ }^{y}$ & $63,000 \quad 70,000$ & 66,5000 & 9,000 & $2,000^{x}$ & 3.5 & 60 trees \\
\hline Sweeper & $24,000-28,000$ & 26,000 & 9,000 & $2,000^{x}$ & 2.0 & 1.2 acres \\
\hline Harvester & $51,000-59,000$ & 55,000 & 9,000 & $2,000^{x}$ & 3.3 & 1.2 acres \\
\hline \multicolumn{7}{|c|}{ Used ( 10 years $)$} \\
\hline Shaker & $30,000-35,000$ & 35,000 & 4,000 & $4,500^{w}$ & 3.5 & 60 trees \\
\hline Sweeper & $10,000-15,000$ & $\mathrm{I} 5,000$ & 4,500 & $3,500^{w}$ & 2.0 & 1.2 acres \\
\hline Harvester & $25,000-30,000$ & 30,000 & 4,500 & $3,500^{w}$ & 3.3 & 1.2 acres \\
\hline
\end{tabular}

${ }^{2}$ All equipment is self-propelled.

Shaker is equipped with brushes and air-conditioned cab.

${ }^{x}$ First 5 years.

"rear 10.

An analysis of the cash cost of owning harvest equipment must include cash flows over a number of years, while the expenditure for hiring a custom operator is a single-year cost. It is incorrect to take the simple average cost of ownership over the useful life of the equipment and compare it to the cost of hiring a custom operator. Most importantly, by investing in harvest equipment, the grower is tying up money that could be generating earnings in another investment. In addition, uncertainty and inflation make a future dollar less valuable than today's dollar.

To account for the level and timing of the grower's expenses, present-value analysis is used to compare the cost of owning harvest equipment to hiring a custom operator. The after-tax cash costs for each year are discounted to their current purchasing power equivalents and added together to calculate the net present value. For equipment with an expected life of 10 years, the following equation is used:

$$
\begin{aligned}
P V= & C_{1} /(1+i)+C_{2} /(1+i)^{2}+ \\
& C_{3} /(1+i)^{3}+\ldots+C_{10} /(1+i)^{10}
\end{aligned}
$$

where $\mathrm{PV}=$ the present value of the cost stream; $\mathrm{C}_{\mathrm{n}}=$ the after-tax costs in year $\mathrm{n}$; and $\mathrm{i}=$ the interest rate used for discounting.

The equivalent annual annuity (EAA) is then calculated from the net present value as follows:

$$
E A A=P V\left\{i /\left[1-(1+i)^{-10}\right]\right\}
$$

The EAA represents the annual cash expenditure of equal amounts that is equivalent to the uneven cash outlays for the harvest equipment purchase and use. This value represents the average of discounted cash costs per year. In other words, if the uneven annual cash flows included in the total after-tax costs could be lumped together and amortized over 10 years, the EAA is the fixed amount of costs that would have to be paid each year. Equipment with unequal annual cash expenses can be compared to one another and to a single year's custom operator's contract by comparing the corresponding EAAs and the custom rate.

Total and annual cash costs of owning and operating new harvest equipment will vary, depending on three factors: acreage harvested, interest rate, and tax rate. Therefore, cost estimates were made for several combinations of these factors. A summary of these results is presented later, but first we will explain how the estimates are calculated.

The details for the combination of factors considered to be most representative of the current situation in California appear in Table 2. The case presented in Table 2 shows the annual cash outlays for a grower intending to keep the new harvest equipment 10 years while harvesting 500 acres annually, making a $40 \%$ down payment, paying $12 \%$ interest on a 5-year loan, and having a marginal tax rate of $28 \%$. Such a grower is expected to face aftertax total annual cash costs of $\$ 48,630$ (expressed in current dollars as the EAA using Eqs. [1] and [2]). This average value does not represent actual cash flows for any particular year. The variables in Table 2 are described briefly.

Dowm payment. This variable represents the total trade-in value expected for the three pieces ofequipment after 4000 to $5000 \mathrm{~h}$ of use. Typically, according to survey respondents, this is the age at which equipment is tradedin. It is common for trade-ins to be used in lieu of cash down payments.

Property taxes and insurance. These amounts are based on the current value of the equipment. In California, county assessors typically apply a given percentage of the purchase price (such as $1 \%$ for taxes) for Year 1 and then gradually reduce that percentage to half of its original amount by Year 10 .

Housing. It is assumed that housing for the equipment does not exist and, therefore, is purchased. Purchased housing for equipment is a depreciating asset, so its cost is deductible according to its depreciation schedule (7-year life is used here). If housing is leased from another firm, the cost is deductible as a fixed operating expense.

Operating costs. All operating costs are adjusted annually for inflation. The labor rate used for an equipment operator is $\$ 8 /$ hour; the rate for field labor is $\$ 6 /$ hour (both include a $34 \%$ benefits margin). Shaking uses one equipment operator, sweeping uses one equipment operator and five field laborers, and pick-up requires two equipment operators. Fuel use is calculated from use per hour and acres harvested per hour for each piece of equipment listed in Table 1 . The cost of diesel fuel is assumed to be $\$ 1 / \mathrm{gal}$. Repair costs are calculated using $\mathrm{C}_{\mathrm{rm}}=$ (RF1) $\mathrm{P}(\mathrm{h} / 1000)^{\mathrm{RF} 2}$ (from the American Society of Agricultural Engineers Standards Yearbook), where $\mathrm{C}_{\mathrm{m}}=$ accumulated repair and maintenance costs; RF1, 2 = repair and maintenance factors; $\mathrm{P}=$ machine purchase price in current dollars; and $\mathrm{h}=$ accumulated use of machine in hours. 
Depreciation. The tax code allows farm machinery to be depreciated as 7-year property under the Alternate Depreciation System of the Modified Accelerated Cost Recovery System. Therefore, the purchase cost is multiplied by the standard percentages: first year, $10.71 \%$; 2nd year, $19.13 \%$; 3rd year, $15.03 \%$; 4th-7th year, $12.25 \%$; and 8th year, $6.13 \%$.

Tax savings. This is the amount that taxes are reduced by writing-off all deductible expenses. To simplify the analysis, only federal rates are used in this paper, but the tax rate used by an individual should combine both federal and state brackets.

The method presented in Table 2 for new equipment was also used to find the EAA for used equipment for the same grower. In the analysis, the fuel and labor costs are the same for the new and used equipment. The cash ownership costs and the repair costs are different for the two sets of equipment, and there is no salvage value for used equipment. The grower is expected to face after-tax total annual costs of $\$ 45,521$, expressed in current dollars as the EAA.

The following points concern the calculation of the cost of used equipment. First, the repair costs are calculated using the formula given above for repairs; however, actual costs could range more widely around the value calculated for an older machine than for a newer model (Hardesty and Carman, 1988). Second, we assume that machines have no salvage value after their normal life span, but this may not be true for well-maintained equipment. Higher salvage values reduce the net cost of owning equipment.

A summary of estimates of annual cash costs of owning and operating new and used harvest equipment appears in Table 3. The estimates vary depending on three factors: acreage harvested, interest rate, and tax rate.
The acreages reported represent three scales of operation across the range that can be handled by a single equipment team during California's 45-day harvest period. The 1000-acre example uses the equipment to its absolute limit of $\approx 19 \mathrm{~h} \cdot \mathrm{day}^{-1}$. This would require two shifts and the use of lights, an uncommon practice.

The effect of acreage on the cost of both new and used equipment is apparent (Table 3) : total costs increase, but costs per acre decrease with increasing acreage. Clearly, the ability to spread fixed ownership costs over more acreage is an advantage of large-scale growers.

Comparing entries for new vs. used equipment, we conclude that used equipment costs less in nearly all cases (Table 3). We note, however, that, as interest rates decline, the amount of the cost difference between new and used equipment declines. At some interest rates, new equipment becomes

Table 2. Annual cash costs (in dollars) oper 10 years for new walnut barvesting equipment.

\begin{tabular}{|c|c|c|c|c|c|c|c|c|c|c|}
\hline \multirow[b]{2}{*}{ Costs } & \multicolumn{10}{|c|}{ Year } \\
\hline & 1 & 2 & 3 & 4 & 5 & 6 & 7 & 8 & 9 & 10 \\
\hline \multicolumn{11}{|l|}{ Ownership } \\
\hline Down payment & 65,000 & & & & & & & & & \\
\hline \multicolumn{11}{|l|}{ Annual loan } \\
\hline payment & 23,811 & 23,811 & 23,811 & 23,811 & 23,811 & & & & & \\
\hline Property taxes & 1,475 & 1,224 & 1,121 & 1,062 & 1,018 & 944 & 885 & 856 & 811 & 738 \\
\hline Insurance & 811 & 679 & 620 & 590 & 561 & 516 & 487 & 472 & 443 & 413 \\
\hline Housing. & 1,000 & 1,000 & 1,000 & 1,000 & 1,000 & 1,000 & 1,000 & 1,000 & 1,000 & 1,000 \\
\hline Total & 92,097 & 26,714 & 26,551 & 26,463 & 26,389 & 2,460 & 2,372 & 2,328 & 2,254 & 2,151 \\
\hline \multicolumn{11}{|l|}{ Operating } \\
\hline Fuel & 4,259 & 4,302 & 4,345 & 4,388 & 4,432 & 4,476 & 4,521 & 4,566 & 4,612 & 4,658 \\
\hline Labor & 28,300 & 28,583 & 28,869 & 29,158 & 29,449 & 29,744 & 30,041 & 30,341 & 30,645 & 30,951 \\
\hline Repairs & 4,219 & 5,567 & 6,547 & 7,345 & 8,031 & 8,639 & 9,188 & 9,692 & 10,160 & 10,597 \\
\hline Total & 36,778 & 38,451 & 39,760 & 40,892 & 41,912 & 42,858 & 43,750 & 44,600 & 45,416 & 46,206 \\
\hline Total cash costs & 128,875 & 65,165 & 66,312 & 67,354 & 68,301 & 45,319 & 46,122 & 46,927 & 47,670 & 48,357 \\
\hline \multicolumn{11}{|l|}{ Deductible expenses } \\
\hline Depreciation & 15,797 & 28,217 & 22,169 & 18,069 & 18,069 & 18,069 & 18,069 & 9,042 & & \\
\hline Interest & 10,300 & 8,679 & 6,863 & 4,829 & 2,551 & & & & & \\
\hline Property taxes & 1,475 & 1,224 & 1,121 & 1,062 & 1,018 & 944 & 885 & 856 & 811 & 738 \\
\hline Insurance & 811 & 679 & 620 & 590 & 561 & 516 & 487 & 472 & 443 & 413 \\
\hline Operating costs & 36,778 & 38,451 & 39,760 & 40,891 & 41,912 & 42,858 & 43,750 & 44,600 & 45,416 & 46,206 \\
\hline Total & 65,161 & 77,249 & 70,533 & 65,441 & 64,110 & 62,387 & 63,191 & 54,969 & 46,670 & 47,357 \\
\hline Tax savings & 18,245 & 21,630 & 19,749 & 18,323 & 17,951 & 17,468 & 17,693 & 15,391 & 13,068 & 13,260 \\
\hline Salvage value & & & & & & & & & & 65,000 \\
\hline Tax on sale & & & & & & & & & & 18,200 \\
\hline Total after-tax & & & & 40030 & 50350 & 27850 & 28428 & 31536 & 34603 & -11703 \\
\hline
\end{tabular}

Net present value of costs over 10 years 274,771

Equivalent annual annuity 
Table 3. Equivalent annual annuity (in dollars) for purchase of new and used walnut harvesting equipment.

\begin{tabular}{|c|c|c|c|c|c|c|}
\hline \multirow{2}{*}{$\begin{array}{l}\text { Interest } \\
\text { rate (\%) }\end{array}$} & \multicolumn{3}{|c|}{$\begin{array}{c}\text { New equipment } \\
\text { Tax rate }(\%)\end{array}$} & \multicolumn{3}{|c|}{$\begin{array}{c}\text { Used equipment } \\
\text { Tax rate (\%) }\end{array}$} \\
\hline & 15 & 28 & 33 & 15 & 28 & 33 \\
\hline \multicolumn{7}{|c|}{100 Acres harvested } \\
\hline 6 & 24,704 & 21,417 & 20,153 & 26,411 & 22,684 & $21,25 \mathrm{I}$ \\
\hline 8 & 26,639 & 23,153 & 21,813 & 27,303 & 23,480 & 22,009 \\
\hline 10 & 28,593 & 24,905 & 23,487 & 28,227 & 24,300 & 22,790 \\
\hline 12 & 30,562 & 26,671 & 25,174 & 29,179 & 25,144 & 23,591 \\
\hline 14 & 32,545 & 28,446 & 26,869 & 30,157 & 26,007 & 24,411 \\
\hline \multicolumn{7}{|c|}{500 Acres harvested } \\
\hline 6 & 50,853 & 43,567 & 40,764 & 50,662 & 43,227 & 40,367 \\
\hline 8 & $52,71 \mathrm{I}$ & 45,238 & 42,363 & 51,488 & 43,965 & 41,072 \\
\hline 10 & 54,590 & 46,926 & 43,979 & 52,346 & 44,731 & 41,802 \\
\hline 12 & 56,487 & 48,630 & 45,608 & 53,236 & 45,521 & 42,554 \\
\hline 14 & 58,399 & 50,346 & 47,248 & 54,154 & 46,334 & 43,326 \\
\hline \multicolumn{7}{|c|}{1000 Acres harvested } \\
\hline 6 & 81,753 & 69,741 & 65,121 & 80,703 & 68,673 & 64,046 \\
\hline 8 & 83,539 & 71,351 & 66,663 & 81,456 & 69,350 & 64,694 \\
\hline 10 & 85,348 & 72,981 & 68,224 & 82,244 & 70,056 & 65,368 \\
\hline 12 & 87,178 & 74,627 & 69,800 & 83,065 & 70,788 & 66,066 \\
\hline 14 & 89,025 & 76,288 & 71,389 & 83,917 & 71,545 & 66,786 \\
\hline
\end{tabular}

less expensive than used machines (e.g., at $6 \%$ and $8 \%$ for 100 -acre operations; Table 3). Yet, to judge the two purchase alternatives, a comparison of costs with custom harvest rates is required.

\section{Custom rates}

Custom rates for harvesting walnuts are contracted on a per-ton basis. Custom operators generally charge a minimum rate of 1 ton/acre and charge the same rate per ton regardless of orchard size. Survey responses indicate that rates in the San Joaquin Valley averaged $\$ 107 /$ ton. The after-tax cost per ton is about $\$ 91, \$ 77$, and $\$ 72$, respectively, for the $15 \%, 28 \%$, and $33 \%$ tax brackets. The per-acre custom charge is found by multiplying the after-tax cost per ton by the yield per acre, and the total custom charge is calculated by multiplying the total production by the custom rate. The custom charges for a 1- and 1.75-ton/ acre yield and the three tax brackets are given in Table 4. About $90 \%$ of the orchards in California should fall within 1 to 1.75 tons/acre. The average yield in California was 1.3 and 1.24 tons/ acre for the past 5 and 10 years, respectively. These averages include young orchards that were not in full production.

Comparing the annual ownership costs in Table 3 to the corresponding custom charges in Table 4 indicates that hiring a custom operator is always the best alternative for growers averaging a 1-ton yield on 100 or 500 acres. Owning (used) equipment is always the best choice for an average 1-ton yield on 1000-acre operations, regardless of the interest rate or tax rate. However, for growers with an average yield of 1.75 tons/acre, the custom charge is higher than the cost of owning and operating equipment for both the 500- and 1000-acre examples. The acreage at which the rankings of the three alternatives changes is discussed in the next section.

\section{Break-even acreage}

The break-even acreage is the orchard size for which the average total annual after-tax ownership (fixed) costs and operating (variable) costs for equipment is the same as the after-tax cost of custom hiring. The break-even acreage is calculated as: break-even acreage $=$ average after-tax ownership costs/( after-tax custom rate per acre after-tax operating cost per acre).

The break-even acreages calculated in this study are presented in Table 5. Four observations can be made concerning these results. First, break-even acreage varies according to interest rates. Higher rates increase owning and operating costs, thus raising the amount ofacreage across which those costs must be spread to remain competitive with custom rates. Second, the effects of tax rates are negligible unless the purchase of equipment moves the grower into another tax bracket; therefore, only the results for the $28 \%$ tax bracket are presented for new and used equipment (Table 5). Third, break-even acreages are lower for used equipment than for new equipment. This is because the total costs for used machinery are lower than for new equipment (Table 3). Finally, the expected yield is a critical factor in the own vs. hire a custom operator decision. The break-even acreage for an average yield of 1 ton is more than three times the break-even acreage for an average yield of 1.75 tons/acre for both new and used equipment. The break-even acreages for new and used equipment are not significantly different at a yield of 1.75 tons, although the break-even acreage for new equipment is much higher

Table 4. After-tax cost (in dollars) of custombarvesting walnuts.

\begin{tabular}{rrrr}
\hline \multirow{4}{*}{$\begin{array}{l}\text { Acres } \\
\text { harvested }\end{array}$} & \multicolumn{4}{c}{ Tax rate (\%) } \\
\cline { 2 - 4 } $\mathbf{4}$ & \multicolumn{3}{c}{$\mathbf{3 3}$} \\
100 & 9,095 & 7,704 & 7,169 \\
500 & 45,475 & 38,520 & 35,845 \\
1,000 & 90,950 & 77,040 & 71,690 \\
\multicolumn{4}{c}{$1.75-$ Ton yield } \\
100 & 15,916 & 13,428 & 12,546 \\
500 & 79,581 & 67,410 & 62,729 \\
1,000 & 159,163 & 134,820 & 125,458 \\
\hline
\end{tabular}


Table 5. Break-epen acreage for purchase of new or used walnut equipment at various yields and interest rates.

\begin{tabular}{ccc}
\hline $\begin{array}{l}\text { Interest } \\
\text { rate (\%) }\end{array}$ & \multicolumn{2}{c}{ Yield (tons/acre) } \\
\cline { 2 - 3 } 1 & 1.75 \\
\hline & New equipment \\
6 & 709 & 206 \\
12 & 906 & 276 \\
14 & 973 & 293 \\
& Used equipment \\
6 & 683 & 215 \\
12 & 768 & 249 \\
14 & 795 & 259 \\
\hline
\end{tabular}

than the break-even acreage for used equipment at a low yield of 1 ton/ acre.

A decision could be reached from the results in Table 4. However, agribusiness decisions cannot be made solely on the basis of anticipated economic conditions. Financial analysis should always consider unanticipated conditions.

\section{Risk factor analysis}

It has been assumed in the basic analysis performed thus far that the quantity and quality of walnuts harvested does not depend on which of the three alternatives is selected. Yet, there are some risks involved in harvesting that vary across the alternatives and may affect a grower's net revenues. These risk factors must be identified and quantified to complete the decision-making process.

Risks in harvesting. The first risk factor to consider is the date ofharvest. Some growers believe that owning harvest equipment allows greater flexibility in timing operations. Since the harvest period for walnuts usually lasts 45 days in California, control over harvest dates can be very valuable; yet, custom operators rarely make a definite commitment concerning the date of harvest. Timing may affect both the quality and quantity of walnuts harvested (Olson and Coates, 1983). Early harvest is important to obtain the highest-quality kernels that are the lightest in color and have the least worm damage. However, harvesting too early will reduce overall yield, because the hulls on many walnuts will not be mature. Harvesting too late will increase the number ofkernels that are infested with molds. Reductions in either quality or quantity will reduce the grower's net revenue, effectively raising the cost of (custom) harvesting. Therefore, this "timing risk" factor generally is considered an incentive to buy equipment for acreages smaller than the calculated break-even levels and to consider new rather than used equipment to avoid repair delays.

The second factor, "efficiency risk," is an incentive to custom harvest. It concerns the efficiency of the harvest operation. In general, the custom operator should be more skilled at operating specialized equipment and should move through the orchard more efficiently than an owner-operator's crew. Payment based on tonnage serves as an incentive for the custom operator to harvest the highest possible yield. For the same reason, custom operators will try to minimize equipment downtime. Custom operators in the survey typically buy new equipment to reduce time and money spent on repairs. Finally, the issue of damage to trees can be important, although most growers interviewed said that damage is not a major problem with walnuts. It is possible that experienced custom operators will cause less damage to tree limbs than owner-operator crews who do not specialize in operating harvest equipment. Yet, growers may be more careful with their own trees. Nonetheless, a custom operator has an incentive to do a good job to keep a grower as a customer in future years.

Risk analysis. After the least costly alternative is identified, choosing either of the other two alternatives indicates that the grower is willing to pay a risk premium to avoid some potential problems inherent in the "best" alternative. For some growers, this may be a rational decision once the risk factors are considered.

To illustrate risk analysis, consider a grower for whom the total annual cost of purchasing new equipment is $\$ 48,630$, used equipment is $\$ 45,521$, and custom costs total $\$ 38,520$ per year. Hiring a custom operator appears to be the least costly alternative. However, the grower is aware of the costs associated with the two risk factors identified earlier and wishes to incorporate them into his analysis.

The risk factor concerning harvest dates adds to the cost of hiring a custom operator. The grower is aware of a neighbor who is growing the same variety in an orchard of equal size and who lost $\$ 90,000$ in 1 year due to worm damage, which could have been avoided if the harvest had not started late. The grower estimates that, in his experience, such a loss is likely to occur only once every 8 years. Therefore, the estimated cost of hiring a custom operator needs to be raised by the cost of this risk factor, calculated as: cost of risk $=$ damage $\times$ probability of occurrence $=(\$ 90,000)(0.125)=\$ 11,250$. The real cost of hiring a custom operator in this example is now estimated to be $\$ 38,520+\$ 11,250=\$ 49,770$.

At this point, the risk analysis has changed the decision. The risk-adjusted cost of hiring a custom operator is now the highest of the three alternatives. The least expensive choice is to purchase used equipment. However, as noted earlier, the time risk factor also may affect the real cost of used equipment. While the basic analysis includes higher estimates of repair costs for used equipment than for new, the grower knows that repair delays also may cause lost revenues. In this example, the grower estimates that an average $\$ 4000$ in revenue losses will occur due to used-equipment downtime each year. This raises the total risk-adjusted cost of used equipment to $\$ 45,521+[(\$ 4000) 1.0]=\$ 49,521$.

In this example, the affect of the timing risk factor made purchasing new equipment the least cost alternative. However, the affect of the efficiency-risk factor also must be evaluated before a final decision is reached. The cost of efficiency risk can be estimated in the same way that the cost of timing risk was estimated in the example above. This may or may not sway the final decision back in favor of hiring a custom operator. The key is to consider all risk factors.

Whereas the decision not adjusted for risk is derived from observable quantities, the risk analysis portion of the decision process is based on estimates of damages and their probabilities of occurring. This means that the final decision is affected significantly by the skill of the grower in estimating the cost of risk for each potential risk factor. Since this is an inexact process, many growers may prefer a different approach to the problem.

Instead of estimating the cost of risk to be added to each of the three harvest alternatives, the risk premium can be evaluated. The risk premium is simply the difference between an alternative's basic cost and the cost of 
the least expensive alternative. In the example above, the two equipment purchase alternatives have a risk premium compared to hiring a custom operator. If the grower is considering the purchase of new equipment, the annual risk premium is $\$ 48,630$ $\$ 38,520=\$ 10,110$. Therefore, to justify the purchase, the grower must believe there are at least $\$ 10,110$ worth of risks associated with hiring a custom operator, an alternative he wishes to avoid. It is not necessary to measure the risks formally, as suggested above; an informal assessment may satisfy the grower. Therefore, this risk premium evaluation process is virtually identical to the process involved in deciding whether or not to purchase insurance.

\section{Summary and conclusions}

Deciding whether to own harvesting equipment or hire a custom operator to perform the job involves analyzing three alternate courses of action: 1) purchase new harvest equipment, 2) purchase used harvest equipment, or 3) hire a custom operator. Total and annual costs of owning and operating harvest equipment will vary depending on three factors: acreage harvested, interest rate, and tax rate. Higher interest rates raise the cost of equipment and, therefore, reduce all firms' incentive to buy. Higher tax rates, however, reduce the after-tax cost of equipment.

In comparing costs for new vs. used equipment in this case study, the general conclusion is that used equip- ment costs less in nearly all cases. The annual costs of new and used equipment are close, however, because California has an active market for used equipment, and the price is bid up to where the average annual cost is almost the same as for new equipment. Of course, the timing and magnitude of the capital outlays are significantly different for new and used equipment and must be taken into account by the firm.

To choose between the three alternatives requires comparing purchase costs with custom harvest rates. This leads to an estimate of the break-even acreage, which is used as a decision criterion. In general, growers would choose to buy equipment if their operations are larger than the break-even acreage, and they would hire a custom operator if their operations are smaller than the break-even size. However, two risk factors need to be included in the decision process: control over the date ofharvest and the efficiency of the harvest operation. The affect of these factors may significantly alter the "real" costs of owning vs. hiring a custom operator and therefore change the decision reached by an individual grower.

\section{Literature Cited}

American Society of Agricultural Engineers. 1990. American Society of Agricultural Engineers Standards Yearbook.

Blank, S.C. 1983. Practical business re- search methods. AVI, Westport, Conn. p. 65-67.

Boehlje, M. and V. Eidman. 1984. Farm management. Wiley, New York. p. 590592.

Franks, J. and S. Hodges. 1987. Lease valuation when taxable earnings are a scarce resource. J. Finance 42:987-1005.

Hardesty, S. and H. Carman. 1988. A case study of California farm machinery: Repair costs and downtime. Giannini Info. Series 88-2, Univ. of California.

Hinman, H. and G. Willet. 1985. Economics ofalternative methods offinancing farm machinery. Farm Business Mgt. Rpts. MCP003D, Washington State Univ.

Lee, W., M. Boehlje, A. Nelson, and W. Murray. 1988. Agricultural finance. 8th ed. Iowa State University Press, Ames. p. 113-117.

Levy, H. and M. Sarnat. 1979. Leasing, borrowing and financial risk. Financial Mgt. 8(Winter):47-54.

Olson, W. and W. Coates. 1983. Maturation, harvesting, and nut quality. In: Walnut orchard management. Univ. of California.

Van Horne, J.C. 1989. Financial management and policy. 8th ed. Prentice Hall, Englewood Cliffs, N. J.

VanTassell, L. and C. Nixon. 1989. To trade or not to trade: A look at asset replacement. J. Amer. Soc. Farm Managers \& Rural Appraisers 53(2):26-33.

Weingartner, H.M. 1987. Leasing, asset lives and uncertainty: Guides to decision making. Financial Mgt. 16(Summer):512. 